\title{
Investigation Of Some Optical And Electrical Properties Of InSe Thin Film, a Window Layer for Photovoltaic Cell Growth on Glass/GaSe Substrate by M- CBD Method
}

\author{
Fatih ÜNAL ${ }^{1 *}$
}

\begin{abstract}
The InSe thin film was successfully grown on a glass/GaSe substrate using the modified chemical bath deposition (MCBD) method and a group was annealed one hour at $80^{\circ} \mathrm{C}$ in atmospheric conditions. The energy band gap $(\mathrm{Eg})$ values of the as-deposited and annealed films were defined $1,89 \mathrm{eV}$ and $1,15 \mathrm{eV}$, respectively. The transmitance values (\%) of the as-deposited and annealed films were asigned $\% 0.65, \% 4.46$ and $\% 11,02, \% 10,35$ at 400 and $700 \mathrm{~nm}$, respectively. The I-V characteristics of the device at different temperatures was examined, the resistivity decreased and the conductivity increased with the increasing temperature. The activation energy in low temperature region was defined $0,05 \mathrm{eV}$, while it was defined $0.6 \mathrm{eV}$ in high temperature region.
\end{abstract}

Keywords: InSe, GaSe, M-CBD, Thin film.

\section{Fotovoltaik Hücrelerde Pencere Tabakası Olarak Kullanılan InSe İnce Filminin Cam/Gase Alt Tabanı Üzerine M-CBD Yöntemiyle Büyütülmesi ve Bazı Optiksel ve Elektriksel Özelliklerinin İncelenmesi}

\section{$\ddot{O} z$}

InSe ince filmi başarılı bir şekilde cam/GaSe alt tabanı üzerine modifiye edilmiş kimyasal banyo depolama (M-CBD) yöntemiyle büyütülmüştür ve üretilen filmlerin bir gurubu atmosfer ortamında bir saat $80^{\circ} \mathrm{C}$ 'de tavlanmıştır. Üretilen ve tavlanan filmlerin enerji band aralıkları sırasıyla 1,89 eV, 1,15 eV olarak belirlenmiştir. Üretilen ve tavlanan filmlerin 400-700 nm'de yüzde geçirgenlik değerleri sirasıyla \%0.65, \%4.46 ve \%11,02, \%10,35 olduğu görülmüştür. Farklı sıcaklıklarda ölçülen I-V krakterizasyonlarında sıcaklığın artmasıyla özdirencin azaldığı, iletkenliğin arttığg görülmüştür. Düşük sıcaklık bölgesinde aktivasyon enerjisi 0,05 eV iken, yüksek sicaklık bölgesinde 0,6 eV olduğu gözlemlenmiştir. Anahtar kelimeler: InSe, GaSe, M-CBD, İnce film. 


\section{Introduction}

$\mathrm{In}_{\mathrm{x}} \mathrm{Se}_{\mathrm{y}}$ compound can be formed different atomic combination and phases like $\mathrm{InSe}, \mathrm{In}_{6} \mathrm{Se}_{7}$ $\mathrm{In}_{4} \mathrm{Se}_{3}, \mathrm{In}_{2} \mathrm{Se}_{3}, \mathrm{In}_{9} \mathrm{Se}_{11}$, etc. have been confirmed as attractiving inorganic semiconductors during past few decades (Igasaki and Fujiwara 1996, Camara, Mauger et al. 2002, Camara, Mauger et al. 2002, Gopal, Viswanathan et al. 2004). Indium selenite $\left(\operatorname{In}_{\mathrm{x}} \mathrm{Se}_{\mathrm{y}}\right)$ belong to $\mathrm{A}^{\mathrm{III}}-\mathrm{B}^{\mathrm{VI}}$ group contains a layered structure similar to the GaS and GaSe compounds. This structure is bounded in two dimensions by covalent bonds and by Van der Waals forces in three dimensions (Choi and Yu 2003). Indium selenite, which can exhibit n-type, has direct band gap (Pathan, Kulkarni et al. 2005). They are of particular interest to researchers because of their remarkable optical and photophysical properties that are promising for capacitors, solar cells, field effect transistors, photovoltaics and a variety of nanoelectronic applications (Mudd, Svatek et al. 2013, Han, Chen et al. 2014, Yuksek, Yaglioglu et al. 2014, Ho and Chu 2015, Boukhvalov, Gurbulak et al. 2017, Politano, Campi et al. 2017, Zhou, Shi et al. 2018). It has been widely researched for its application especially in photovoltaic device fabrication (Gopal, Viswanathan et al. 2005). $\operatorname{In}_{\mathrm{x}} \mathrm{Se}_{\mathrm{y}}$ has been used either as a windows layer (ElSayed 2003) in CIS/ $\mathrm{In}_{\mathrm{x}} \mathrm{Se}_{\mathrm{y}}$ as well as an absorber layer (Julien, Chevy et al. 1990) in $\mathrm{In}_{\mathrm{x}} \mathrm{Se}_{\mathrm{y}} / \mathrm{CdS}$ solar cell. There are number of deposition techniques such as flash evaporation (Julien, Benramdane et al. 1990), molecular beam epitaxy (Zhou, Shi et al. 2018), chemical vapor deposition (Jin-Ho Park, Mohammad Afzaal et al. 2003), van der walls epitaxy (Lang, Klein et al. 1995) and vacuum evaporation (Gopal, Viswanathan et al. 2005) for preparation of $\operatorname{In}_{\mathrm{x}} \mathrm{Se}_{\mathrm{y}}$ thin films. However, the modified chemical bath deposition (M-CBD) method is an simple, low temperature and inexpensive technique that could fabricate films with high quality for device applications such as heterojunction devices, switching etc. (Lokhande and Pawar 1989).

In this study, we have coated the InSe semiconductor on glass/GaSe thin film substrate for MCBD method and examined its optical and electrical properties. It is aimed to synthesize glass/GaSe/InSe heterojunction at low cost, examine their optical and electrical properties, and as a result, to present them as an alternative material that can be used in the construction of opto-electronic circuit elements.

\section{Material and Methods}

InSe thin films were deposited at room temperature on glass/GaSe(hexagonal) thin film substrate of $3 \times 3 \mathrm{~cm}$ dimensions by M-CBD method. For cationic solutions, acidic $(\mathrm{pH} \approx 3) \operatorname{In}_{2}\left(\mathrm{SO}_{4}\right)_{3}$ solutions of $0.07 \mathrm{M}$ concentrations were used while for anionic ones, basic $(\mathrm{pH} \approx 12) \mathrm{Na}_{2} \mathrm{SeSO}_{3}$ solution of $0.05 \mathrm{M}$ was used. 
The glass/GaSe substrates were 60 times immersed in $\mathrm{In}_{2}\left(\mathrm{SO}_{4}\right)_{3}$ precursor solution for 30 seconds, in distilled water for 70 seconds, in $\mathrm{Na}_{2} \mathrm{SeSO}_{3}$ precursor solution for 10 seconds and distilled water for 70 seconds respectively. The two of the fabricated films were also annealed at $80{ }^{\circ} \mathrm{C}$ temperatures in air atmosphere for one hour.

Optical properties were investigated by Perkin-Elmer Lambda 25 UV-Vis spectrophotometer. The I-V measurements were carried out with Keithley 6486 pico-amperometer and Pasco Scientific SF-9585 A power source using two probe technique in which silver metal was used for contacts.

\section{Findings and Discussion}

\subsection{Optical Properties}

The thickness of InSe thin film growth on glass/GaSe substrate in 60 steps was estimated to be $90 \mathrm{~nm}$.

The optical absorbance and transmittance spectra against wavelength in the range $400-1100$ $\mathrm{nm}$ at room temperature for glass/GaSe/InSe film is shown in Figure 1a and c, respectively. The graph of the absorption coefficient $\left(\alpha_{a}\right)$ versus photon energy is given in Figure 1b. The highest value of $\alpha_{a}$ is $9,3 \times 10^{6}$ at $2,26 \mathrm{eV}$. As seen in Figure $1 \mathrm{a}$, the maximum absorption peak is $547 \mathrm{~nm}$ in the UV region and the absorption decreases with increasing wavelength. This behavior is a characteristic feature of existence of states with free carries that localized in the energy band gap (ÜNAL, IZGİ et al. 2020). Figure $1 \mathrm{c}$ also plotted wavelength versus percent transmitance. Glass $/ \mathrm{GaSe} / \mathrm{InSe}$ thin film is highly transmitance at wavelengths greater than $700 \mathrm{~nm}$ but the transmittance value at 400 and 700 $\mathrm{nm}$ is $\% 0.65, \% 4.46$, respectively. These values are very low and mean that the glass $/ \mathrm{GaSe} / \mathrm{InSe}$ thin film is a good absorbent material at the visible region boundaries.

The basic absorption spectrum is one of the most used methods to determine the energy band gap $\left(E_{g}\right)$. The relation between absorption coefficient and energy band gap is given (Tauc 1968)

$\alpha(h v) \approx\left(h v-E_{g}\right)^{n}$

where $\alpha$ is the absorption coefficient and $h v$ is the energy of absorbance light. The value of $\mathrm{n}$ is $1 / 2$ for direct allowed transitions for InSe (Gopal, Viswanathan et al. 2005) materials. This method uses the plot of $(\alpha h v)^{\frac{1}{n}}$ versus hv (Figure $1 \mathrm{~d}$ ). $E_{g}$ is determined by extrapolating the straight line portion of this plot to the energy axis. The intercept on energy axis gives the value of $E_{g}$, and have yielded $1.89 \mathrm{eV}$. It is seen that the result obtained is lower than the energy band gaps of metal oxide semiconductor films(Dugan, Koç et al. 2020, Yetim, Aslan et al. 2020). 

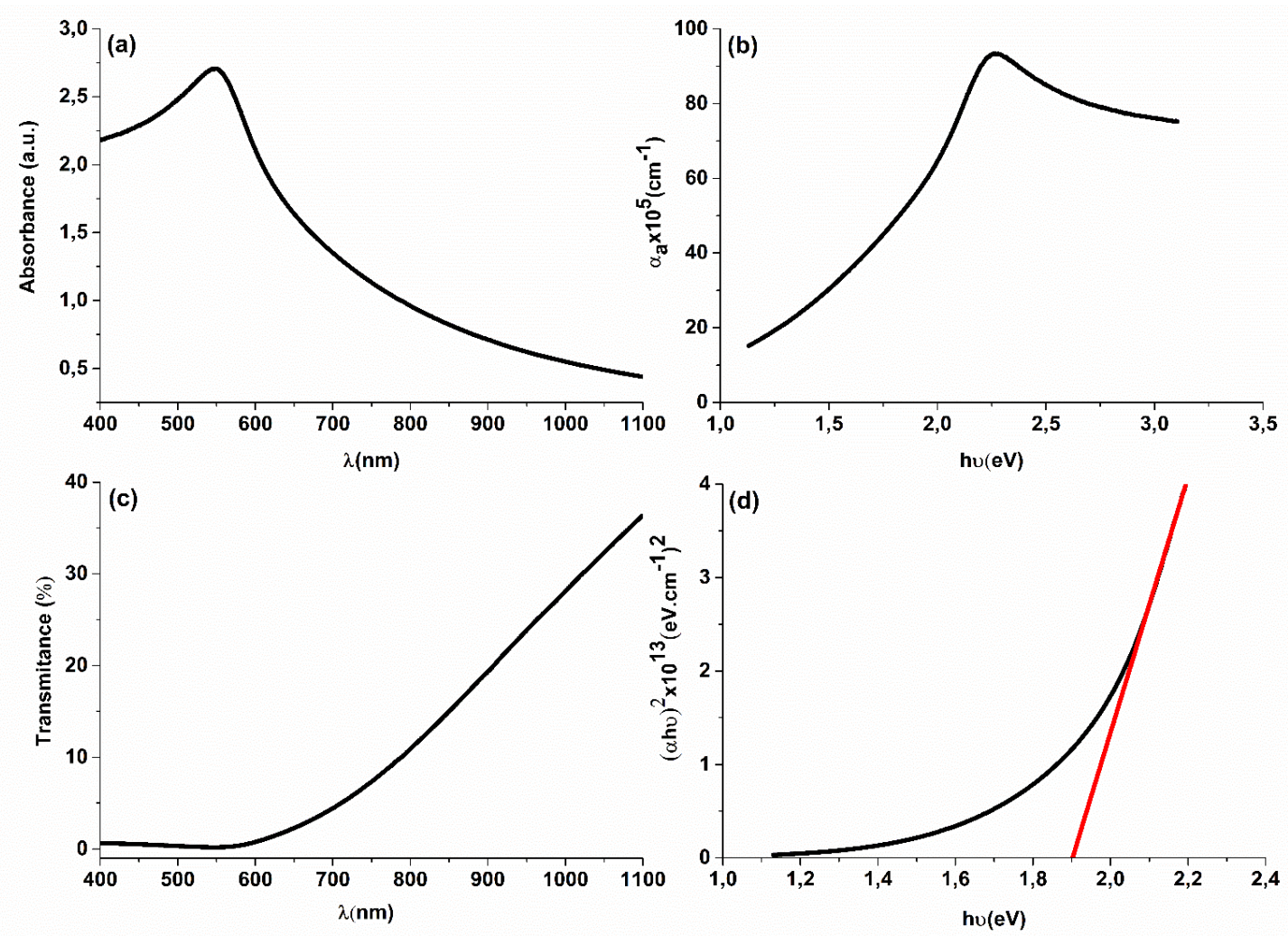

Figure 1. The optical spectrum of glass/GaSe/InSe thin films: a) absorbance, b) absorbtion coefficient, c) transmittance and d) the photon energy dependence of $(\alpha h v)^{2}$.

Optical absorption and transmittance plotted against the 400-1100 nm wavelength of glass $/ \mathrm{GaSe} / \mathrm{InSe}$ (annealed) thin film are given in Figure 2a and c, respectively. The absorption coefficient $\left(\alpha_{\mathrm{a}}\right)$ and $(\alpha h v)^{2}$ plotted against photon energy are given in Figure $2 \mathrm{~b}$ and $\mathrm{d}$, respectively. The highest value of $\alpha_{\mathrm{a}}$ is $3,5 \times 10^{6}$ at $1,49 \mathrm{eV}$. As seen in Figure $2 \mathrm{a}$, the highest absorption was seen at $837 \mathrm{~nm}$. With the effect of annealing, the highest absorption peak shifted from the visible to the infrared region. This caused the forbidden energy band gap to decrease to $1.15 \mathrm{eV}$, as seen in Figure 2d. In Figure 2c, the visible region boundaries at 400-700 $\mathrm{nm}$ are $\% 11,02$ and $\% 10,35$ percent transmittance values, respectively. The transmitance values of the film increased with annealing. This may be due to the absorption shift from the visible to the infrared region. The transmitance values of the glass $/ \mathrm{GaSe} / \mathrm{InSe}$ (annealed) thin film increased with annealing. 

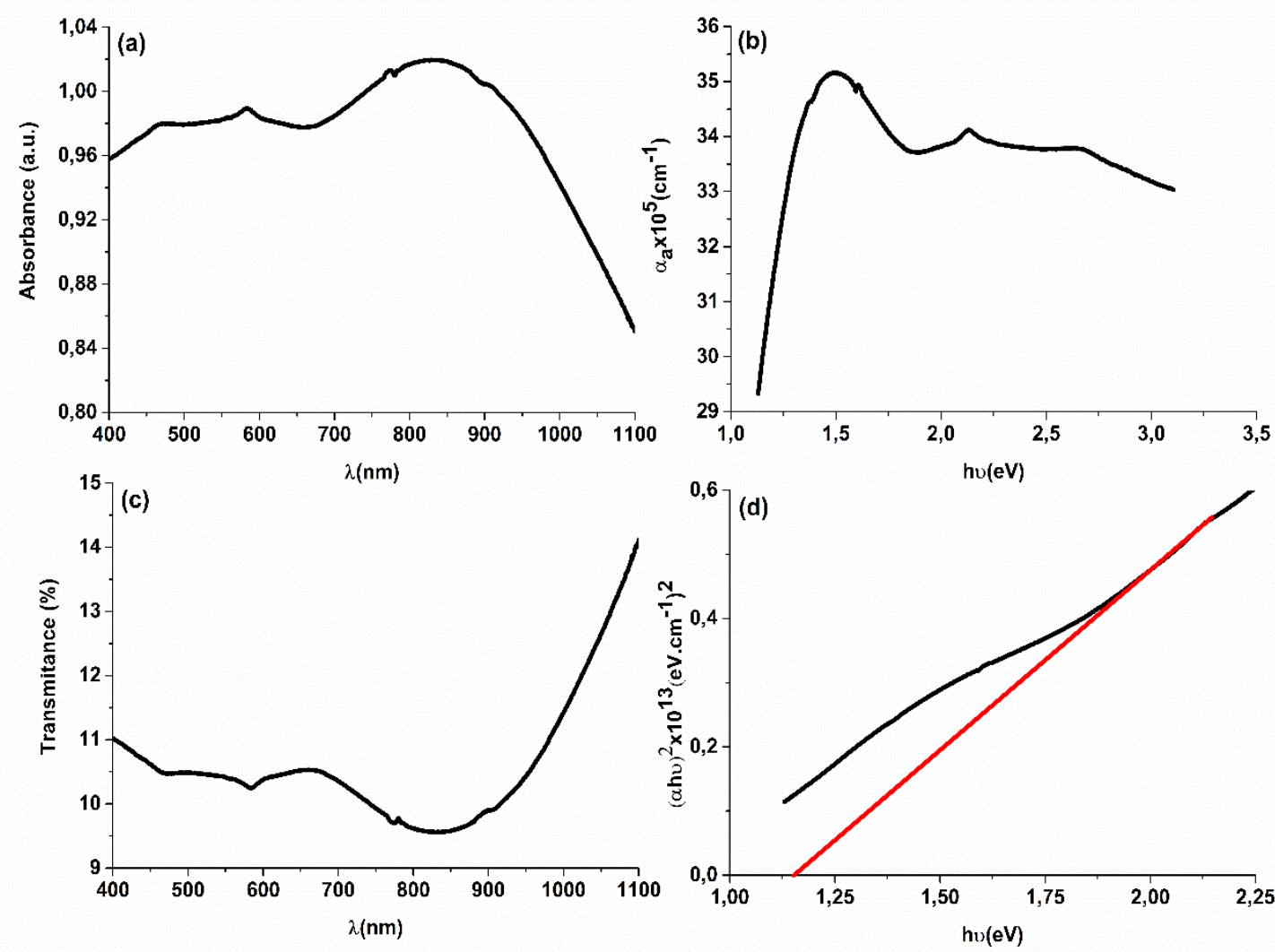

Figure 2. The optical spectrum of glass/GaSe/InSe(annealed) thin films: a) absorbance, b) absorbtion coefficient, c) transmittance and d) the photon energy dependence of $(\alpha h v)^{2}$.

\subsection{Electrical Properties}

The I-V characteristics of the as-deposited and annealed films were examined under dark and yellow light intensity $100 \mathrm{w} / \mathrm{m}^{2}$. Figure 3 a shows the schematic representation of the device produced, Fig 4a shows the current graph plotted against the voltage in the dark and light environment, and $4 \mathrm{~b}$ shows the graphs of the junction resistance $\operatorname{Rj}\left(R j=\frac{\partial V}{\partial I}\right)$ versus voltage.

In Figure 4a, it is seen that both as-deposited and annealed films are sensitive to light and their electrical conductivity increases under light. It is also seen that the photoconductivity of the asdeposited film is higher than that of the annealed film. The reason for this can be shown, as seen in the optical analysis, the shift of the maximum absorption peak from the visible to the infrared region, the decrease in the maximum absorption coefficient and the increase in the transmitance in the visible region. It is also seen that there are three different regions in Figure. 4a. The first region suggests a trap controlled space charge limited. The second region is the region of superquadratic behavior caused by low concentration charge carriers. In the second region, the trap filling mechanism is dominant. In the 3rd region, as the application voltage increases, all trap levels in the band gap of the semiconductor layer are filled. This suggests that most of traps are filled and contribution of free 
carrier to electric filed becomes appreciable (Kumar, Jain et al. 2003, Yakuphanoglu 2008, Chaudhary, Kumar et al. 2019).

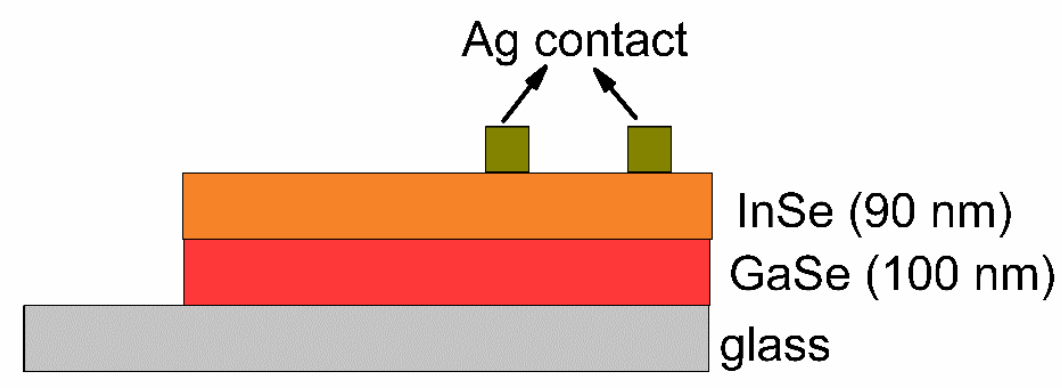

Figure 3. Schematic representation of the fabricated device.
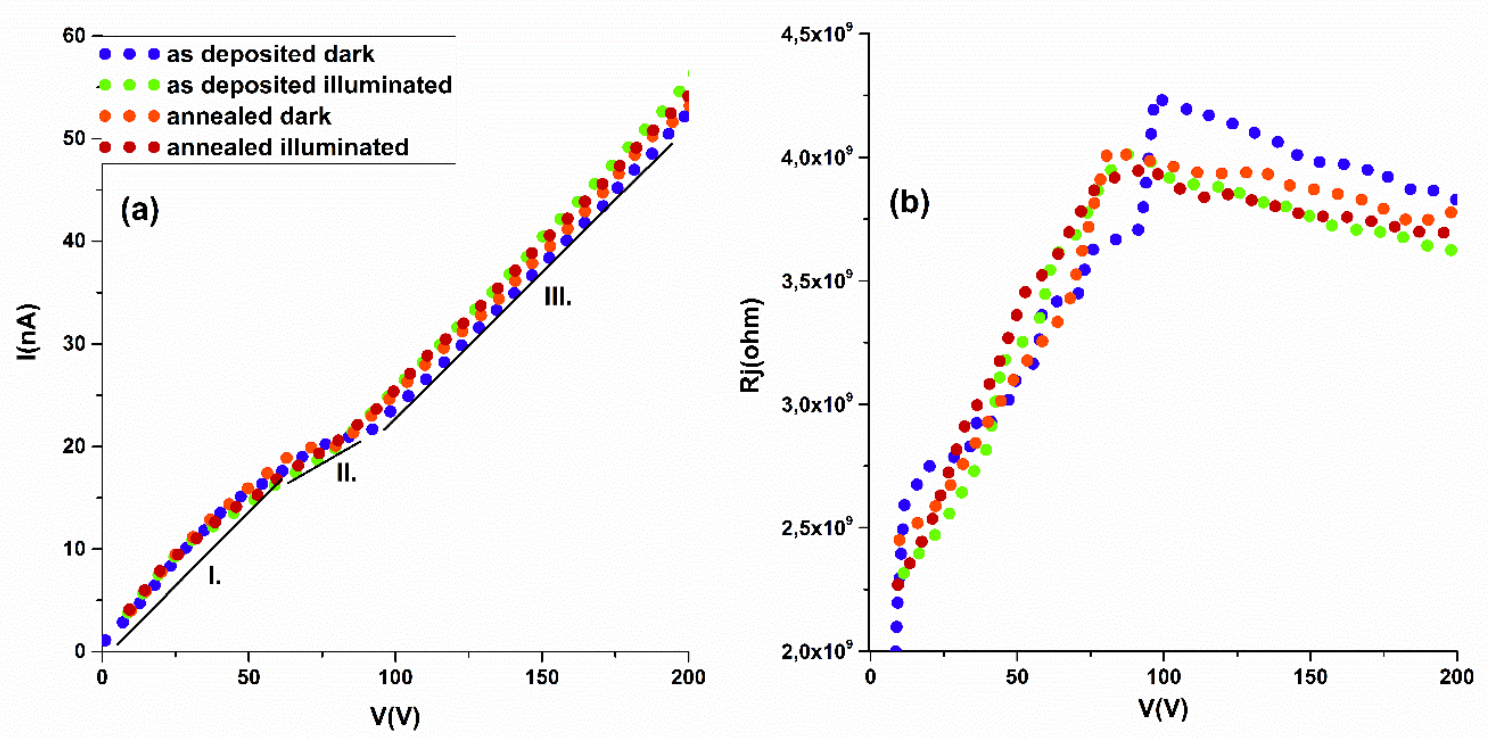

Figure 4. a) I-V characteristics of non-annealed and annealed devices, b) $\mathrm{Rj}-\mathrm{V}$ characteristics of nonannealed and annealed devices

Figure $5 \mathrm{a}$ and $\mathrm{b}$ shows I-V and $\mathrm{Rj}-\mathrm{V}$ graphs against temperature change, respectively. With the increase in temperature, the electrical conductivity increased with the decrease of $\mathrm{Rj}$. In Figure 6a and $b$, graphs of resistivity and conductivity versus temperature are given at a constant potential, respectively. While the resistivity was determined as $0.7 \times 10^{9}(\mathrm{ohm} . \mathrm{cm})$ at $285^{\circ} \mathrm{K}$, it was determined as $0.1 \times 10^{9}$ (ohm.cm) at $407^{\circ} \mathrm{K}$. The conductivity was determined as $1,3 \times 10^{-9}$ (ohm.cm) $)^{-1}$ at $285^{\circ} \mathrm{K}$ and $6,6 \times 10^{-9}(\mathrm{ohm} . \mathrm{cm})^{-1}$ at $407{ }^{\circ} \mathrm{K}$. This is one of the biggest properties that distinguishes semiconductors from metals. 

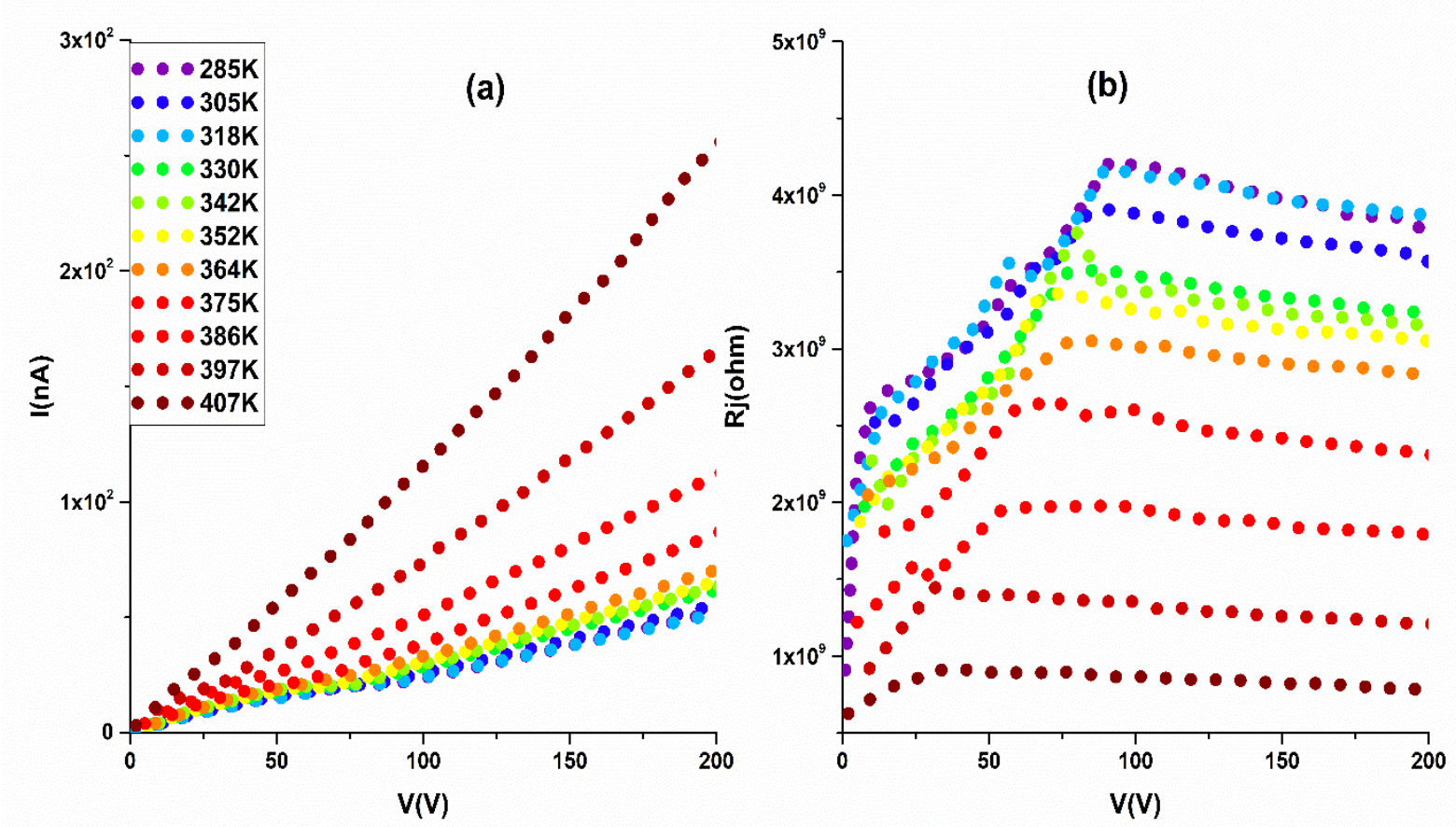

Figure 5. Temperature-dependent a) I-V characteristics, b) Rj-V characteristics of the as-deposited film.

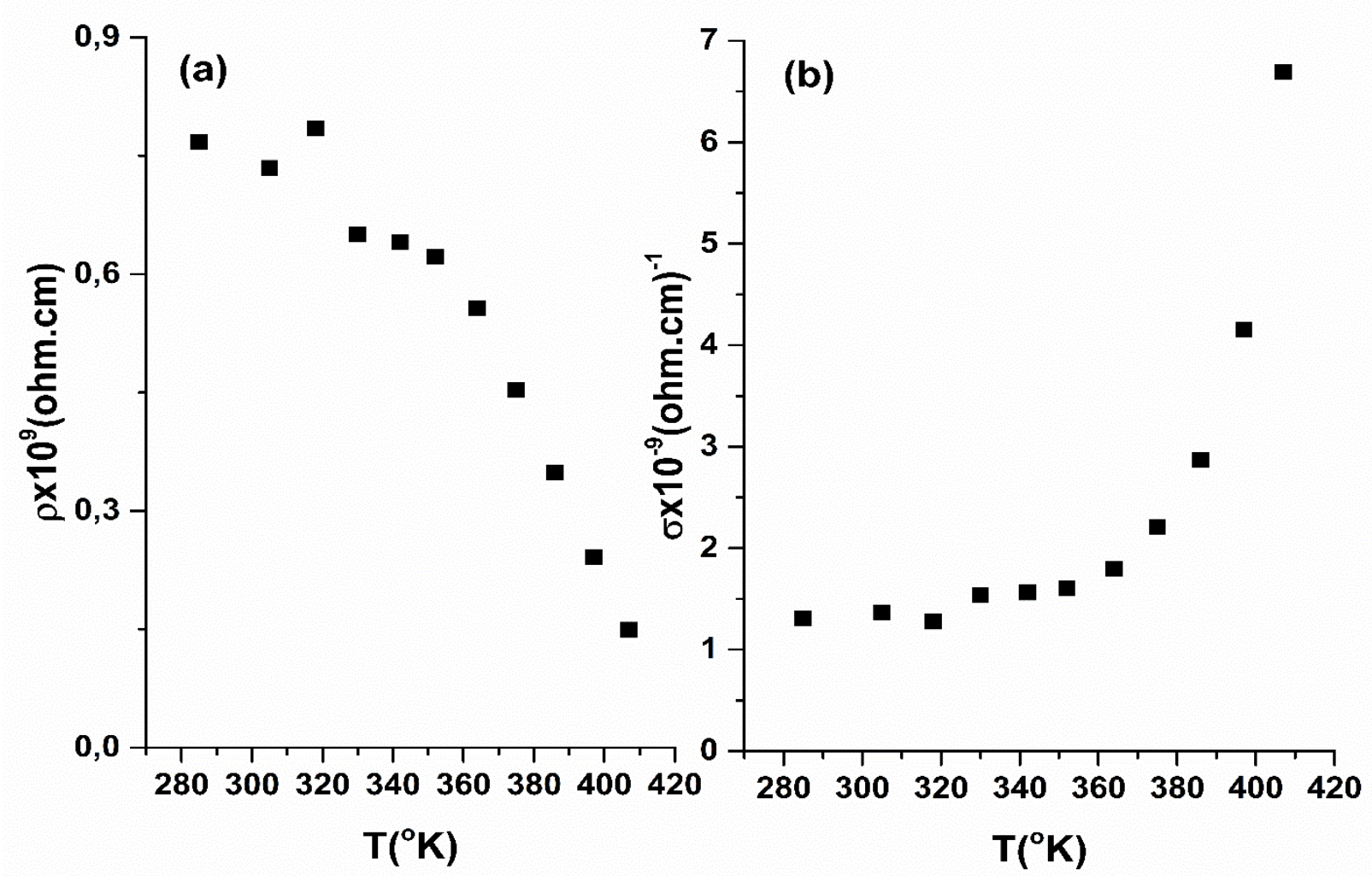

Figure 6. Temperature-dependent a) resistivity, b) conductivity of the as-deposited film. 
,Also activation energies for as-deposited film were calculated within $285-407^{\circ} \mathrm{K}$ temperature range and corresponding $\log \sigma-10^{3} / \mathrm{T}$ plots were recorded. The calculations were made according to following equation (Kobbi and Kesri 2004, Yilmaz 2008):

$$
\sigma=\sigma_{0} \exp (-\Delta E / k T)
$$

The $\log \sigma-10^{3} /$ T curve depicted in Figure 7 in this temperature range represent that the activation energy in low temperature region $\left(285-342^{\circ} \mathrm{K}\right)$ is $0,05 \mathrm{eV}$, it is $0,23 \mathrm{eV}$ in middle temperature region $\left(352-375^{\circ} \mathrm{K}\right)$ while it is $0.6 \mathrm{eV}$ in high temperature region $\left(386-407^{\circ} \mathrm{K}\right)$. The increment in conductance is non-linear owing to presence of amorphous structure of the film (Pathan, Kulkarni et al. 2005).

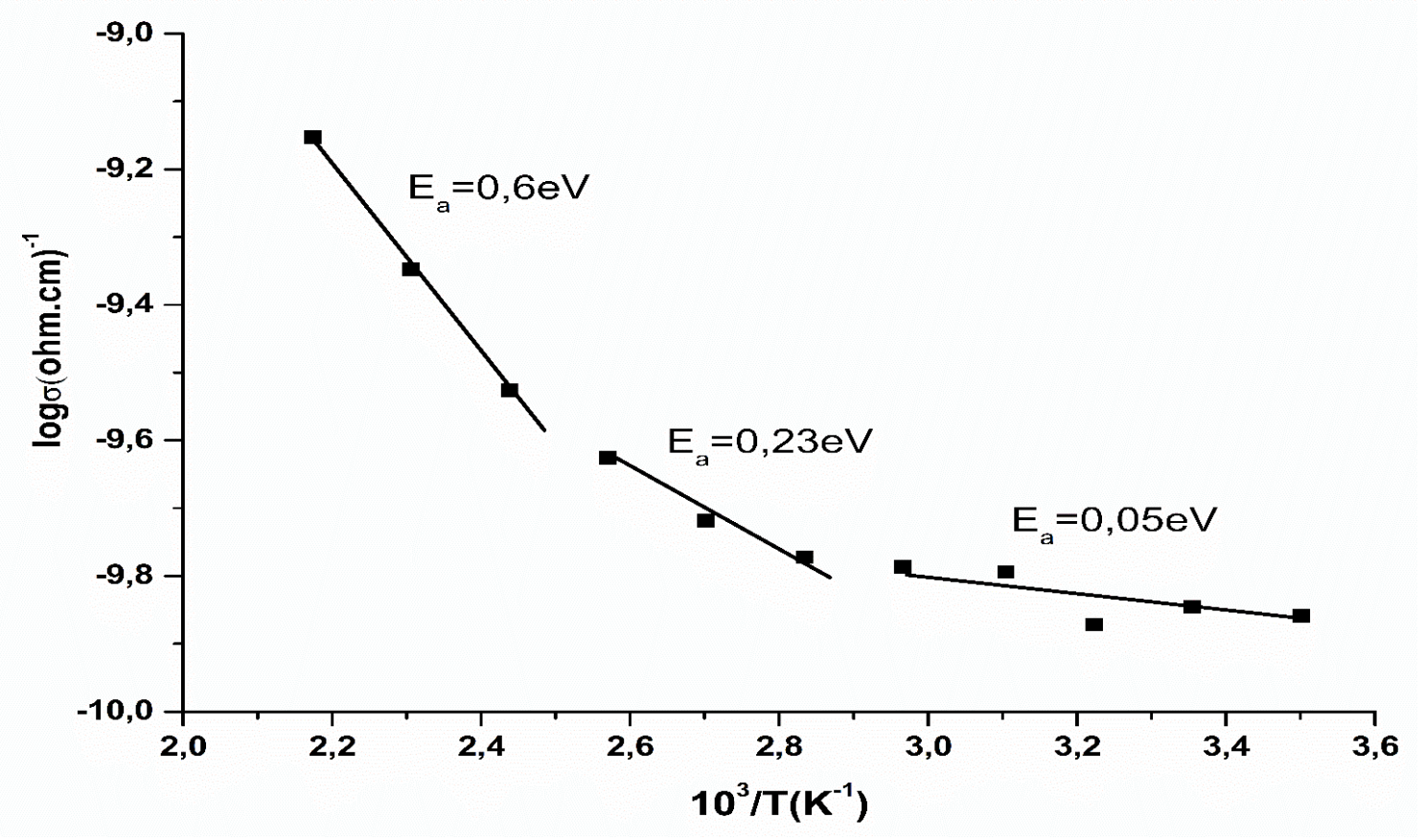

Figure 7. Arrhenius plot of the conductance of device $(\mathrm{T}=$ absolute temperature $)$

\section{Conclusions and Recommendations}

The InSe thin film was successfully grown on a glass/GaSe substrate using the M-CBD method and a group was annealed. While the energy band gap of the as-deposited film was $1.89 \mathrm{eV}$, the energy band gap of the annealed film was determined as $1.15 \mathrm{eV}$. The maximum absorption region shifted from the visible to the infrared region by annealing. The as-deposited device is ideal for optoelectronic applications in the visible region, while the annealed film is ideal for applications used in 
the infrared region. In addition, with annealing while the maximum absorption coefficient $\alpha_{\mathrm{a}}$ decreased, optical transmittance and electrical conductivity increased.

The I-V characterization of the device at different temperatures was examined, the resistivity decreased and the conductivity increased with the increase of the temperature. The activation energy in low temperature region is $0,05 \mathrm{eV}$, while it is $0.6 \mathrm{eV}$ in high temperature region.

\section{Acknowledgements}

Thank you to Mr. Prof. Dr. Hasan MAMMADOV for his contribution.

\section{Authors' Contributions}

Fatih ÜNAL: Experimetal, Investigation, Formal analysis, Writing - review \& editing.

\section{Statement of Conflicts of Interest}

There is no conflict of interest between the authors.

\section{Statement of Research and Publication Ethics}

The author declares that this study complies with Research and Publication Ethics.

\section{References}

Boukhvalov, D. W., B. Gurbulak, S. Duman, L. Wang, A. Politano, L. S. Caputi, G. Chiarello and A. Cupolillo (2017). "The Advent of Indium Selenide: Synthesis, Electronic Properties, Ambient Stability and Applications." Nanomaterials 7(11).

Camara, M. O. D., A. Mauger and I. Devos (2002). "Electronic structure of the GaSe/Si(111) and InSe/Si(111) heterojunctions." Physical Review B 65(20).

Camara, M. O. D., A. Mauger and I. Devos (2002). "Electronic structure of the layer compounds GaSe and InSe in a tight-binding approach." Physical Review B 65(12).

Chaudhary, V., N. Kumar and A. K. Singh (2019). "Solubility dependent trap density in poly (3hexylthiophene) organic Schottky diodes at room temperature." Synthetic Metals 250: 88-93.

Choi, I. H. and P. Y. Yu (2003). "Properties of phase-pure InSe films prepared by metalorganic chemical vapor deposition with a single-source precursor." Journal of Applied Physics 93(8): 4673-4677.

Dugan, S., M. M. Koç and B. Coşkun (2020). "Structural, electrical and optical characterization of Mn doped CdO photodiodes." Journal of Molecular Structure 1202: 127235.

El-Sayed, S. M. (2003). "Optical investigations of the indium selenide glasses." Vacuum 72(2): 169-175.

Gopal, S., C. Viswanathan, B. Karunagaran, S. K. Narayandass, D. Mangalaraj and J. Yi (2005). "Preparation and characterization of electrodeposited indium selenide thin films." Crystal Research and Technology 40(6): 557-562. 
Gopal, S., C. Viswanathan, M. Thamilselvan, K. Premnazeer, S. K. Narayandass and D. Mangalaraj (2004). "Conduction studies on electrodeposited indium selenide thin films." Ionics 10(3-4): 300-303.

Han, G., Z. G. Chen, J. Drennan and J. Zou (2014). "Indium Selenides: Structural Characteristics, Synthesis and Their Thermoelectric Performances." Small 10(14): 2747-2765.

Ho, C. H. and Y. J. Chu (2015). "Bending Photoluminescence and Surface Photovoltaic Effect on Multilayer InSe 2D Microplate Crystals." Advanced Optical Materials 3(12): 1750-1758.

Igasaki, Y. and T. Fujiwara (1996). "The preparation of highly oriented InSe films by electrodeposition." Journal of Crystal Growth 158(3): 268-275.

Jin-Ho Park, Mohammad Afzaal, Madeleine Helliwell, Mohmmad A. Malik, Paul O’Brien and J. Raftery (2003). "Chemical Vapor Deposition of Indium Selenide and Gallium Selenide Thin Films from Mixed Alkyl/Dialkylselenophosphorylamides." Chem. Mater. 15: 4205-4210.

Julien, C., N. Benramdane and J. P. Guesdon (1990). "Transformation steps of structure in flash-deposited films of a-InSe." Semiconductor Science and Technology 5(8): 905-910.

Julien, C., A. Chevy and D. Siapkas (1990). "Optical properties of In2Se3 phases." physica status solidi (a) 118(2): 553-559.

Kobbi, B. and N. Kesri (2004). "Physico-chemical and electrical properties of InSe films." Vacuum 75(2): 177-182.

Kumar, V., S. C. Jain, A. K. Kapoor, J. Poortmans and R. Mertens (2003). "Trap density in conducting organic semiconductors determined from temperature dependence of J-V characteristics." Journal of Applied Physics 94(2): 1283-1285.

Lang, O., A. Klein, R. Schlaf, T. Löher, C. Pettenkofer, W. Jaegermann and A. Chevy (1995). "InSeGaSe heterointerfaces prepared by Van der Waals epitaxy." Journal of Crystal Growth 146(1): 439-443.

Lokhande, C. D. and S. H. Pawar (1989). "Electrodeposition of Thin Film Semiconductors." physica status solidi (a) 111(1): 17-40.

Mudd, G. W., S. A. Svatek, T. Ren, A. Patane, O. Makarovsky, L. Eaves, P. H. Beton, Z. D. Kovalyuk, G. V. Lashkarev, Z. R. Kudrynskyi and A. I. Dmitriev (2013). "Tuning the Bandgap of Exfoliated InSe Nanosheets by Quantum Confinement." Advanced Materials 25(40): 5714-+.

Pathan, H. M., S. S. Kulkarni, R. S. Mane and C. D. Lokhande (2005). "Preparation and characterization of indium selenide thin films from a chemical route." Materials Chemistry and Physics 93(1): 16-20.

Politano, A., D. Campi, M. Cattelan, I. Ben Amara, S. Jaziri, A. Mazzotti, A. Barinov, B. Gurbulak, S. Duman, S. Agnoli, L. S. Caputi, G. Granozzi and A. Cupolillo (2017). "Indium selenide: an insight into electronic band structure and surface excitations." Scientific Reports 7.

Tauc, J. (1968). "Optical properties and electronic structure of amorphous Ge and Si." Materials Research Bulletin 3(1): 37-46.

ÜNAL, F., T. İZGİ, B. BARIŞ and S. KARADENIZ (2020). "Cam/ITO/CIS/Rubrene Heteroekleminin Yüzey ve Optiksel Özelliklerinin İncelenmesi." Karadeniz Fen Bilimleri Dergisi 10.

Yakuphanoglu, F. (2008). "Photovoltaic properties of the organic-inorganic photodiode based on polymer and fullerene blend for optical sensors." Sensors and Actuators A: Physical 141(2): 383-389.

Yetim, N. K., N. Aslan, A. Sarıoğlu, N. Sarı and M. M. Koç (2020). "Structural, electrochemical and optical properties of hydrothermally synthesized transition metal oxide (Co3O4, $\mathrm{NiO}, \mathrm{CuO})$ nanoflowers." Journal of Materials Science: Materials in Electronics 31(15): 12238-12248.

Yilmaz, S. (2008). "TETRAGONAL $\left(\mathrm{Bi}_{2} \mathrm{O}_{3}\right)_{1-x}\left(\mathrm{Ln}_{2} \mathrm{O}_{3}\right)_{x}$ İKILI İ SISTEMLERINDE IYYONIK İLETKENLIĞİN İNCELENMESİ VE KATKI CINNSINE BAĞLILIĞI ( $\mathrm{Ln}=\mathrm{Dy}, \mathrm{Eu}, \mathrm{Sm}) . "$ Erciyes Üniversitesi Fen Bilimleri Enstitüsü Dergisi 24: 212-215.

Yuksek, M., H. G. Yaglioglu, A. Elmali, E. M. Aydin, U. Kurum and A. Ates (2014). "Nonlinear and saturable absorption characteristics of Ho doped InSe crystals." Optics Communications 310: 100-103.

Zhou, J., J. Shi, Q. Zeng, Y. Chen, L. Niu, F. Liu, T. Yu, K. Suenaga, X. Liu, J. Lin and Z. Liu (2018). "InSe monolayer: synthesis, structure and ultra-high second-harmonic generation." 2D Materials 5(2).

Zhou, J. D., J. Shi, Q. S. Zeng, Y. Chen, L. Niu, F. C. Liu, T. Yu, K. Suenaga, X. F. Liu, J. H. Lin and Z. Liu (2018). "InSe monolayer: synthesis, structure and ultra-high second-harmonic generation." 2d Materials 5(2). 